\title{
Competition and price stickiness: Evidence from the French retail gasoline market
}

\author{
Sylvain Benoit* Yannick Lucotte ${ }^{\dagger}$ Sébastien Ringuedé
}

October 1, 2018

\begin{abstract}
Using daily price quotes from about 8,000 French gas stations, this paper empirically analyses whether the level of competition determines the degree of price stickiness on the retail gasoline market. The degree of price rigidity is measured by the frequency of price changes, while the distance to the nearest station and the number of gas stations within a given radius are considered as proxies for local competition. The results confirm that local competition is an important determinant of the price-setting behavior of gas stations. Indeed, considering Ordinary Least Squares (OLS) and spatial regression models, we find that the degree of price rigidity is positively related to the distance to the nearest station, and negatively related to the concentration of firms in a given geographical area. This result can be notably explained by the fact that gas stations facing a high competitive pressure are more likely to adjust their prices more quickly and more frequently in response to crude oil price decreases than stations enjoying market power.
\end{abstract}

Keywords: Retail gasoline pricing, Price-setting behavior, Price stickiness, Local competition

JEL Codes: D40, L11, L81, Q43

*Université Paris-Dauphine, PSL Research University, LEDa, 75016 PARIS, FRANCE. E-mail: sylvain.benoit@dauphine.fr

'Université d'Orléans, CNRS, LEO, FRE 2014, F45067, Orléans, France \& PSB Paris School of Business. Corresponding author. E-mail: ylucotte@gmail.com

${ }^{\ddagger}$ Université d'Orléans, CNRS, LEO, FRE 2014, F45067, Orléans, France. E-mail: sebastien. ringuede@univ-orleans.fr. 


\section{Introduction}

An important factor determining firms' pricing behavior is the market structure. An extensive academic literature in industrial economics has investigated this issue. In particular, a great deal of attention has been devoted to the question of whether price inertia depends on the degree of market competition. It is often argued that firms operating in competitive markets are more likely to adjust more quickly and more frequently their prices in response to cost and demand shocks than firms enjoying market power. Indeed, the opportunity cost of not adjusting prices to optimal ones is very high for firms in competitive markets (Ginsburgh and Michel, 1988; Martin, 1993). Moreover, as stressed by Encaoua and Geroski (1986), firms in more competitive industries face higher uncertainty about their future position in the market. Consequently, they may be more concerned with ensuring short-run returns, which leads to a higher responsiveness to current shocks. By contrast, pricing policies of firms facing less competition are more oriented by long-run objectives than by short-run costs or demand fluctuations, resulting in a higher price rigidity. Alternatively, Stiglitz (1984) argues that oligopolists may prefer delays in adjusting prices in order to avoid breaking tacit pricing understandings.

A number of empirical studies have investigated the link between competition and price flexibility across different industries. Among the pioneer papers on this issue, we find for instance Dixon (1983), Carlton (1986), Bedrossian and Moschos (1988) and Weiss (1995) on the manufacturing sectors, while Hannan and Berger (1991) focus on the banking industry. Overall, these studies tend to support the existence of a greater price rigidity in markets characterized by higher levels of concentration, viewed as an inverse proxy for market competition. Furthermore, Hannan and Berger (1991) show that the degree of price rigidity is asymmetric. Deposit rates are significantly more rigid when the stimulus for a change is upward rather than downward. More recently, the existence of a negative relationship between competition and price rigidity has been documented on the basis of surveys on pricing-setting behavior of firms (see, e.g., Alvarez and Hernando, 2006; Cornille and Dossche, 2006; Fabiani et al., 2006). For instance, these studies use a measure of perceived competition as a proxy for market competition, measured as the importance a firm attaches to competitors' prices when considering reducing its own prices. Results obtained by these studies corroborate previous findings. The frequency of price adjustment and the speed of adjustment is positively related to the degree of competition.

Within this line of research, the present paper revisits the relationship between the intensity of market competition and the degree of price stickiness by focusing on the French retail gasoline market. Several points have motivated this research. First, due to expansion of vehicle fleet and increasing consumption of fuel, retail gasoline prices 
and the pricing strategies that fuel retailers adopt directly impact consumer welfare. The price-setting behavior of gas stations is the object of an active public debate, one that typically centers around the suspicion of a non-competitive pricing behavior. Second, contrary to the studies cited above, we have information on the geographical location of firms. Then, we are able to assess the degree of local competition between firms, which is certainly a more appropriate measure of market competition than the concentration within an industry or the perceived competition. Third, the characteristics of the retail gasoline market imply that it is particularly suitable for comparing the rigidity of prices between firms and investigating the role played by competition. Indeed, retail gasoline is a fairly homogeneous product, and all firms in the market face the same cost shocks, induced by the changes in the wholesale price. Moreover, contrary to other industries, the menu costs, also known as the "cost for updating prices", are relatively low. Consequently, they are not a source of price rigidity, and do not explain why some gas stations show a relatively low price flexibility. Finally, to the best of our knowledge, it is one of the first empirical studies with the recent papers of Gautier and Le Saout $(2015,2017)$ that formally investigates whether the degree of spatial competition is a driver of price stickiness on the retail gasoline market 1 .

To this end, we use individual gasoline prices collected at a daily frequency for more than 8,000 French gas stations. Following the existing literature, we consider the frequency of price changes as a inverse measure of price stickiness. Concerning the degree of local competition, it is proxied by the distance in kilometers $(\mathrm{km})$ to the nearest station and the number of gas stations within a $3 \mathrm{~km}, 5 \mathrm{~km}$ and $10 \mathrm{~km}$ radius. As expected, after having controlled for some other potential determinants of price stickiness, our results suggest that the intensity of local competition reduces the rigidity of retail gasoline prices. They also indicate that the degree of price stickiness of gas stations strongly depends on the price-setting behavior of their local competitors.

The rest of the paper is organized as follows. Section 2 gives an overview of previous empirical studies having investigated the relationship between competition and retail gasoline prices. Section 3 describes the data used and the measures of price stickiness and competition considered. Section 4 presents our empirical analysis and discusses the results. Section 5 concludes.

\footnotetext{
${ }^{1}$ Note, however, that the empirical investigation conducted by Gautier and Le Saout (2015) is somewhat different from our analysis in this article. The authors analyse whether the degree of passthrough from the wholesale price to retail prices depends on the degree of local competition, but do not investigate the link between competition and the frequency of price changes. Moreover, the measure of local competition they consider just relies to the competition between traditional gas stations and stations associated to supermarkets. They find that gas stations respond more slowly to changes in their costs if the competition pressure from supermarket gas stations is relatively low.
} 


\section{Competition and retail gasoline prices: A literature overview}

In response to antitrust and regulatory concerns, the empirical literature on gasoline retailing has been growing rapidly over the last three decades. Much of this literature focuses on retail gasoline price dynamics and is concerned with understanding how and why prices change over time. As argued by Gautier and Le Saout (2015), gasoline prices appear as a textbook to investigate price dynamics, since price changes in gas stations are known to be infrequent whereas wholesale gasoline prices, and then marginal costs, change every day. In particular, since the seminal study of Borenstein et al. (1997), there has been an explosion of empirical work examining whether retail prices respond asymmetrically to positive and negative shocks to crude oil prices and wholesale gasoline prices ${ }^{2}$. However, empirical findings are mixed and often depend on the market considered, on the frequency and the level of aggregation of data used (see, e.g., Bachmeier and Griffin, 2003; Geweke, 2004 for a discussion), and on the econometric approach (Douglas, 2010). Moreover, as documented by the meta-analysis of Perdiguero-Garcia (2013), results also exhibit some degree of publication bias.

Given these conflicting results, the literature extends the analysis by investigating the factors that may explain why retail gasoline prices respond faster to wholesale price increases than to equivalent wholesale price decreases. Among the potential sources of pass-through asymmetry, the consumer search behavior and the focal price collusion theories are certainly those that have received the most attention in the literature. The former, developed by Yang and Ye (2008), Tappata (2009), Lewis (2011) and Cabral and Fishman (2012), is based on the idea that the willingness of consumers to engage in costly search, and hence the elasticity of demand faced by firms, is influenced by the magnitude and the direction of price changes. In particular, it is assumed that consumers are more likely to search intensely following a cost increase than a decrease. Such a purchasing behavior of retail gas consumers is confirmed by Hastings and Shapiro (2013), who show that consumers are more price sensitive when prices increase. Consequently, knowing this purchasing behavior, gas stations will have lower incentive to decrease price following a cost decrease than to increase price following a cost increase, which leads to asymmetric price adjustments. The recent papers by Remer (2015) and Lewis (2011) on the US retail gasoline market find evidence in favor of the consumer search-based theory.

Based on the "trigger price" model of Green and Porter (1984), Borenstein et al. (1997) hypothesize that a focal price collusion can also explain the asymmetric pricing

\footnotetext{
${ }^{2}$ Note that Bacon (1991) first demonstrated for the UK market that retail gasoline firms respond with greater speed to wholesale price increases than decreases. He was the first one to use the term "rockets and feathers" to describe this asymmetric pricing phenomenon, gasoline prices shooting up like rockets but falling like feathers. This expression is now frequently used in the literature on gasoline retailing. Asymmetric pricing, however, is not confined to the retail gasoline industry. Peltzman (2000) provides evidence that such a pattern is common across other industries as well.
} 
behavior of stations. The focal price collusion theory suggests that when wholesale prices fall, previous retail prices may act as focal points around which gasoline retailers can collude. Consequently, stations are more likely to maintain their past prices when wholesale gasoline prices decrease. On the other hand, stations would immediately raise retail prices in response to wholesale price increases, because continuing to charge past prices would be unprofitable. Asymmetric adjustment results because collusion delays price reductions but not price increases. Empirically, a number of studies on different jurisdictions find evidence consistent with the collusion explanation for asymmetric pricing in the retail gasoline industry. The recent empirical evidence provided by Lewis (2015) on the U.S. gasoline retail market also suggests that the use of odd prices can be an effective mechanism for tacitly coordinating prices. Indeed, he finds that stations that rely more heavily on odd prices, particularly those ending in 5 or 9 , tend to have higher margins.

Considering that tacit collusion is generally easier and more sustainable in concentrated markets, several authors have investigated whether the structure of gasoline retail markets and the degree of market power of firms can explain asymmetric adjustments of retail prices. The first empirical paper on this issue is from Deltas (2008). Using monthly state level US data, Deltas (2008) shows that markets with higher average retail-wholesale margins, and then a higher degree of retail market power, experience a slower adjustment and a more asymmetric response. In other words, asymmetric adjustments are more prevalent in less competitive gasoline retail markets. Results obtained by Verlinda (2008) and Balmaceda and Soruco (2008), using station level data in Southern California and Chile, respectively, confirm that stations with greater market power exhibit greater price-response asymmetry. In particular, Verlinda (2008) shows that the asymmetric pricing behavior decreases with the geographical proximity of fuel retailers, confirming that the degree of competitiveness is a key driver of retail price asymmetries. Furthermore, Balmaceda and Soruco (2008) find that the degree of pass-through asymmetry is different for branded gas stations and unbranded stations, the branded stations having a more asymmetric price-adjustment pattern than unbranded stations, as may be expected under a collusive explanation.

Based on the Edgeworth cycle model proposed by Edgeworth (1925) and formalized in Maskin and Tirole (1988), Eckert (2003) and Noel (2007a, 2007b) show for the Canadian gasoline market that competitive local markets tend to have short-lived price cycles (or not cycle at all), while isolated and less competitive markets often exhibit long periods of price stability and month-long cycles. Edgeworth cycles are then another way to explain the inverse relationship between competition and asymmetric gasoline pricing ${ }^{3}$.

\footnotetext{
${ }^{3}$ See Eckert (2013) for a complete literature review on Edgeworth cycles in gasoline pricing, while an overview of methods of identifying Edgeworth cycles can be found in Zimmerman el al. (2013).
} 
In parallel to this literature on fuel retail price trajectories, we find a large empirical literature that investigated the determinants of price levels and their dispersion. In particular, this literature has examined whether fuel retail prices are associated with market power and spatial competition. Using data at the level of the city or state, the first studies on this issue typically estimate reduced form price equations to analyse how market structure and concentration may affect competitive pricing behavior, and then price levels. Using average monthly retail prices across eleven Canadian cities over the 1991-1997 period, Sen (2003) finds that the local retail market concentration, measured by the Hirschman-Herfindahl index, is positively and significantly associated with gasoline retail prices. However, results are not statistically significant when the market concentration is proxied by the density of stations. In another study on the same gasoline market, Sen (2005) shows that this positive relationship between concentration and average retail prices is particularly evident when the market share of small and independent gasoline retailers is relatively high. Sen (2005) explains this result by the fact that an increase in market concentration among smaller firms reduces the market concentration among vertically integrated firms, and then results in lower average retail prices. Similar results are obtained by Hastings (2004) using data from the San Diego and Los Angeles Metropolitan areas.

Clemenz and Gugler (2006) re-examined the results of Sen (2003) in the case of Austria, using the 121 political districts of Austria as regional units. However, they do not consider the average gasoline retail price as dependent variable, but the average retail margin. A negative relationship is expected between the density of gasoline stations, proxied by the number of stations within a district, and the margin. Moreover, Clemenz and Gugler (2006) take into account the fact that the locational choice of stations, and then the stations density, is not exogenous to the district characteristics, notably the level of demand for gasoline, which can impact the prices set by retailers. Despite these methodological differences, results obtained by Clemenz and Gugler (2006) support those of Sen (2003). Indeed, they find a negative and significant relationship between the density of gasoline stations and the average retail margin, and their results are robust when they change the level of aggregation by considering Austrian cities. More recently, Angelopoulou and Gibson (2010) obtained similar results in the case of Greece. Using aggregate data at the prefecture level, they find that the number of gasoline retailers in a given region, viewed as a proxy for competition, has a negative and significant impact on the average retail prices. However, as suggested by Van Meerbeeck (2003) on the Belgian retail gasoline market, the size of this effect is relatively small.

With the increasing availability of high-frequency station level price data, much attention has been paid to the determinants of cross-sectional price dispersion, and especially the role played by the competition. In contrast to previous studies, this 
literature does not consider the market concentration at the level of the city or state as a proxy for competition, but generally uses latitude and longitude information at the station level to capture the degree of spatial competition between fuel retailers. Among the proxies for spatial competition commonly used in the literature, we find in particular the distance to the nearest competitor and the number of stations within a certain radius (see, e.g., Haucap et al., 2017; Kihm et al., 2014; Hosken et al., 2008; Eckert and West, 2005; Barron et al., 2004). For example, Hosken et al. (2008) and Barron et al. (2004) consider the number of stations within a 1.5 mile radius, while Haucap et al. (2017) and Eckert and West (2005) employ a $2 \mathrm{~km}$ radius. Pennerstorfer and Weiss (2013) also propose an alternative measure of "spatial clustering", based on the model of Salop (1979).

In general, whatever the market and the fuel type considered, the findings suggest a significant relationship between the degree of spatial competition and the level of fuel retail prices, even if in some cases results appear relatively sensitive to the composition of the sample of stations (see, e.g., Hosken et al., 2008). Results show that individual station prices are positively associated with the distance to the nearest competitor, and negatively with the station density within a given radius. Thus, in line with expectations, an increased spatial competition has a direct impact in lowering the price. Furthermore, as suggested by Haucap et al. (2015) on the German market, it seems that the degree of competition also drives the volatility of retail prices, approximated in their case by the number of price changes per day. Haucap et al. (2017) find that the distance to the nearest competitor significantly decreases price volatility, while the inverse relationship is found when they consider the number of competitors in a $2 \mathrm{~km}$ radius as a proxy for spatial competition.

Finally, a small number of papers have also examined whether the relationship between competition and fuel retail prices can play through the degree of information of consumers. Indeed, as suggested by the "clearinghouse model" introduced by Varian (1980) and further developed by Stahl (1989), the degree of information can impact the pricing strategy of firms, and then the dispersion and the level of prices on a given market. At the very extremes, this model predicts prices uniformity. If no consumer has access to the information concerning all the prices charged in a given market, all firms will charge the monopoly price. Conversely, if all consumers are fully informed, this corresponds to the Bertrand situation, and all firms will charge a price equal to the marginal cost. Consequently, one can expect that the degree of information of consumers has a negative impact on price levels.

Pennerstorfer et al. (2014) have recently investigated this issue on the Austrian retail gasoline market by using the commuter flows as a proxy for the degree of information. Indeed, as they argue, commuters can freely sample gasoline prices along their daily commuting path and then, have access to the "clearinghouse". Moreover, 
as suggested by Marvel (1976), the important role of commuters on firms' pricing decisions can also be explained by the fact they tend to purchase more fuel than their non-commuting counterparts, and therefore gain more information regarding the price distribution on the market. After having controlled for the degree of spatial competition, results that Pennerstorfer et al. (2014) obtain show that the share of informed consumers faced by a gas station has a negative and significant impact on price levels. More precisely, going from a situation of no informed consumers to a situation where all consumers are fully informed would reduce prices by about 2 cents. This result reinforces previous findings from Houde (2012), who shows for the Québec City gasoline market that gas stations facing a high share of home-to-work commuters enjoy relatively little market power, especially compared to a situation in which consumers are located at a single point.

\section{Data}

Our dataset consists of individual gasoline prices reported by all French gas stations selling more than $500 \mathrm{~m}^{3}$ of gasoline per year. The data were manually collected at a daily frequency from a governmental website (www.prix-carburants.gouv.fr) for the period from May 2nd, 2012 to April 30th, 2013. Indeed, since January 2007, gas stations have to report all their price changes to the Ministry of Economy. Retail prices are available for several types of gasoline (diesel, SP95, E10, SP95-E10, E85, and LPG). In this paper, we focus on diesel prices, since it is the product for which we have the larger number of observations. Moreover, in contrast to the North America, diesel-engined vehicles represent a relatively large share of the vehicle fleet in France, accounting for more than $50 \%$ of the total car stock in 2009 (Harding, 2014). All retail prices are nominal end-customer prices in Euro per liter with three decimals and includes all taxes and duties (i.e. the value-added tax and the domestic tax on petroleum products). These taxes represent about $65 \%$ of the diesel price per liter. All in all, after correcting for some measurement errors, our sample consists of about 2.8 millions of daily price quotes from 8,064 gas stations.

Using price quotes for each station on the overall period, we have computed the frequency of price changes (STICKY), which measures the degree of price stickiness. The frequency of price changes is defined as the number of price changes during the overall period divided by the number of opening days, and is expressed in percentage. Since gas stations report one price per day to the Ministry of Economy, this index is comprised between 0 and 100. A value of zero corresponds to a situation where a gas station never changes its prices during the period considered, while a value of 100 corresponds to a situation where a gas station changes its prices each day. Then, the frequency of price changes is an inverse proxy for price stickiness. This variable has 
been extensively used in the literature on consumer prices stickiness (see, e.g., Baudry et al., 2007; Bils and Klenow, 2004). Moreover, this cross-sectional measure of price rigidity is particularly suitable for our study since all firms on the gasoline retail market face the same cost shocks. Based on the results from Eckert (2003) and Noel (2007a, $2007 \mathrm{~b}$ ), we expect a positive relationship between the degree of local competition and the frequency of price changes.

The spatial distribution of gas stations and the degree of local competition faced by firms are computed using the geo-coordinates of each station provided by the dataset. Following the existing literature, we consider four alternative variables for proxying the degree of competition: the distance in $\mathrm{km}$ to the nearest gas station (COMP1), the number of stations within a $3 \mathrm{~km}$ (COMP2), a $5 \mathrm{~km}$ (COMP3), and a $10 \mathrm{~km}$ radius (COMP4).

Beyond these alternative proxies for local competition, we also control for other characteristics of gas stations that could explain their price-setting behavior. In particular, one would expect that the type of retailer is an important determinant of the degree of price stickiness. The French market of gasoline consists of four types of retailers: (i) stations belonging to major oil companies like Total, Esso, BP, Shell,..; (ii) stations associated to supermarkets, which are located very close or in supermarkets; (iii) small independent retailers; (iv) stations located on motorways 4 . Based on this classification, we construct two dummy variables. The first takes the value of one if a gas station is associated to a supermarket chain, and zero otherwise. The second takes the value of one if a gas station is an independent retailer, and zero otherwise. Consequently, as our sample does not include stations on highways, this means that gas stations belonging to major oil companies are considered as the reference.

In the same vein, we control for the number of services offered in a gas station. Indeed, the database details the type of services offered by each gas station. Twentyfour different services are distinguished, such as as the presence of stores, restaurants, car washes, and ATMs. The variable that we consider is the total number of services offered in a gas station. We also capture the differences in terms of pricing policy by controlling for the price level. For each gas station, it corresponds to the average daily price over the considered period. Intuitively, a high price level means that a gas station has certainly less responded, or more slowly, to wholesale price decreases. Then, we expect a positive relationship between the price level and the degree of price rigidity.

The degree of price stickiness can also depend on the characteristics of the local

\footnotetext{
${ }^{4}$ Please note that we do not consider in our sample gas stations located on highways. Indeed, the demand addressed to stations on highways is specific, in the sense that drivers rarely leave the motorway to buy gasoline in urban areas, implying that competition on highways is mainly between firms operating in this sector. Moreover, since these stations often belong to major oil companies and face different demand profiles, one would expect a different pricing policy than stations operating in urban areas.
} 
market, and especially on the demand addressed to each individual gas station. Since we have no information on the volume of sales and the traffic intensity, we merge our dataset with municipal and departmental data obtained from the French National Institute of Statistics and Economic Studies (INSEE). Following the existing literature, we consider several variables for approximating the local demand, and then the potential demand addressed to each individual gas station. Thus, we first control for the city size where the gas station is located. To this end, similar to Gautier and Le Saout $(2015,2017)$, we consider three binary variables. The first is equal to one if the gas station is located in a medium-size city, corresponding to an urban area with 20,000 to 100,000 inhabitants, and zero otherwise. The second is equal to one if the gas station is located in a major urban centre with more than 100,000 inhabitants, and zero otherwise. The last is equal to one if the gas station is located in Paris and its region, and zero otherwise.

Furthermore, we consider a dummy variable equal to one if the gas station is located in a rural area, and zero otherwise. Indeed, due a relatively low level of demand, gas stations located in a rural area often practice a different pricing policy than stations located in urban areas. In particular, the low volume of sales in rural areas implies that a large number of rural gas stations change their sales prices only when they receive a new delivery of fuel, in order to preserve their margins. Consequently, a higher price rigidity is expected for rural gas stations.

Finally, the second set of control variables aims at capturing the socio-economic conditions and the local population characteristics, and then the demand profile of the market. In line with recent empirical papers on retail gasoline prices, four different variables are considered: the logarithm of the annual median household income (Eckert and West, 2005; Chouinard and Perloff, 2007), the unemployment rate (Sen, 2003; Gautier and Le Saout, 2015, 2017), the number of campings (Pennerstorfer and Weiss, 2013), and the share of households owning a car (Chouinard and Perloff, 2007; Gautier and Le Saout, 2017) ${ }^{5}$. The first three variables are available at the city-level and come from the census 2012, while the share of households owning a car is only available at the departmental level.

\section{Empirical analysis}

Based on the insights from the existing literature and on the arguments developed above, our empirical analysis aims at testing whether the frequency of price changes is negatively related to the distance to the nearest gas station, and positively related

\footnotetext{
${ }^{5}$ More precisely, Pennerstorfer and Weiss (2013) consider the number of overnight stays of tourist per month divided by the number of inhabitants of the municipality as measure of tourism intensity. However, we do not have access to such data
} 
to the concentration of gas stations in a given radius. Nonetheless, before turning to the econometric analysis, this section presents some preliminary findings on the relationship between the level of local competition and the degree of price rigidity.

\subsection{Preliminary findings}

Table 1 reports the coefficients of correlation between our measure of price stickiness and the four proxies for local competition. As expected, we find a negative and significant correlation between the distance to the nearest gas station (COMP1) and the frequency of price changes (STICKY). Thus, geographical proximity of stations seems to decrease the rigidity of gasoline prices. Concerning the variables of spatial competition based on the number of gas stations within a given radius, we also obtain the expected results. The correlation between these three variables (COMP2, COMP3, COMP4) and the frequency of price changes is positive and statistically significant.

In Table 2, we test whether the degree of price rigidity differs according to the intensity of local competition. To this end, we conduct mean comparison tests by considering for each competition measure the two extremes of the distribution, namely the 25 th and the 75 th percentiles. Concerning the distance in $\mathrm{km}$ to the nearest station, the 25th percentile contains gas stations facing high competition, and the 75th percentile firms that experience the lower competitive pressure. Conversely, if we consider the competition measures based on the concentration of competitors within a given radius, the 25 th percentile refers to the lower degree of local competition and the 75th percentile to the greater degree of competition. Results show that, on average, gas stations facing the greater competitive pressure exhibit a higher frequency of price changes.

Finally, Figure 1 plots the fitted regression lines obtained by regressing our measure of price stickiness on the different competition proxies. Results that we obtain confirm previous findings. Indeed, we find a negative relationship between the distance to the nearest station and the frequency of price changes, while this link is positive when we consider competition proxies based on the number of gas stations within a given radius. 
Table 1: Correlation matrix

\begin{tabular}{lccccc}
\hline & STICKY & COMP1 & COMP2 & COMP3 & COMP4 \\
\hline STICKY & 1.0000 & & & & \\
COMP1 & $-0.1836^{*}$ & 1.0000 & & & \\
COMP2 & $0.1901^{*}$ & $-0.3932^{*}$ & 1.0000 & & \\
COMP3 & $0.1988^{*}$ & $-0.3242^{*}$ & $0.9188^{*}$ & 1.0000 & \\
COMP4 & $0.1673^{*}$ & $-0.2393^{*}$ & $0.7911^{*}$ & $0.9214^{*}$ & 1.0000 \\
\hline \hline
\end{tabular}

Note: Correlation coefficients are calculated on the total sample of gas stations $(8,064$ observations). COMP1 refers the distance in $\mathrm{km}$ to the nearest gas station, COMP2, COMP3 and COMP4 refer to the number of stations within a $2 \mathrm{~km}$, a $5 \mathrm{~km}$, and a $10 \mathrm{~km}$ radius, respectively. STICKY corresponds to the frequency of price changes. The asterisk denotes that the correlation is significant at the $10 \%$ level.

Table 2: Mean comparison tests

\begin{tabular}{lcc}
\hline & 25th Percentile & 75th Percentile \\
\hline & Distance in km to the nearest gas station \\
\hline Frequency of price changes & $21.855^{*}$ & $17.497^{*}$ \\
\hline & Number of stations within a $3 \mathrm{~km}$ radius \\
\hline Frequency of price changes & $17.846^{*}$ & $25.471^{*}$ \\
\hline & Number of stations within a $5 \mathrm{~km}$ radius \\
\hline Frequency of price changes & $16.538^{*}$ & $25.881^{*}$ \\
\hline Frequency of price changes & Number of stations within a $10 \mathrm{~km}$ radius \\
\hline \hline
\end{tabular}

Note: Mean comparison tests are conducted on the total sample of gas stations $(8,064$ observations). They aim at comparing the degree of price stickiness according to the intensity of local competition. For each competition measure, the two extremes of the distribution are considered, i.e. the 25 th and the 75 th percentiles. The asterisk denotes a statistically significant difference at the $10 \%$ level.

\subsection{OLS estimates}

To gauge the relationship between the level of local competition and the degree of rigidity of diesel retail prices, we estimate the following cross-sectional equation:

$$
\text { Sticky }=\gamma \text { Comp }+\beta X+\varepsilon
$$

where Sticky is a $n \times 1$ vector of observations on the dependent variable represent- 
Figure 1: Local competition and frequency of price changes - Fitted regression lines
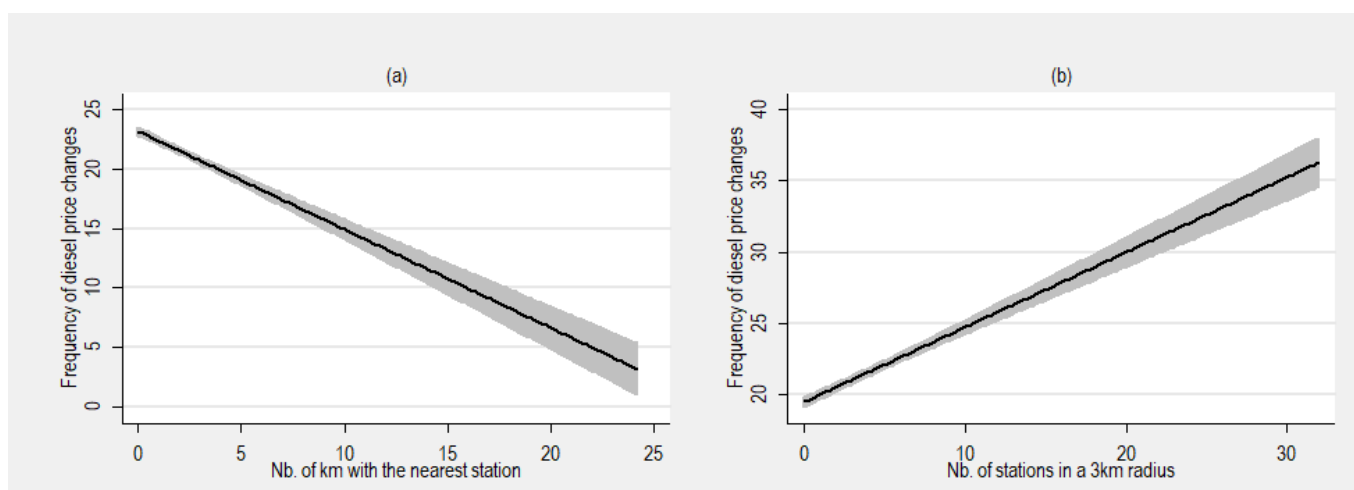

(c)

(d)
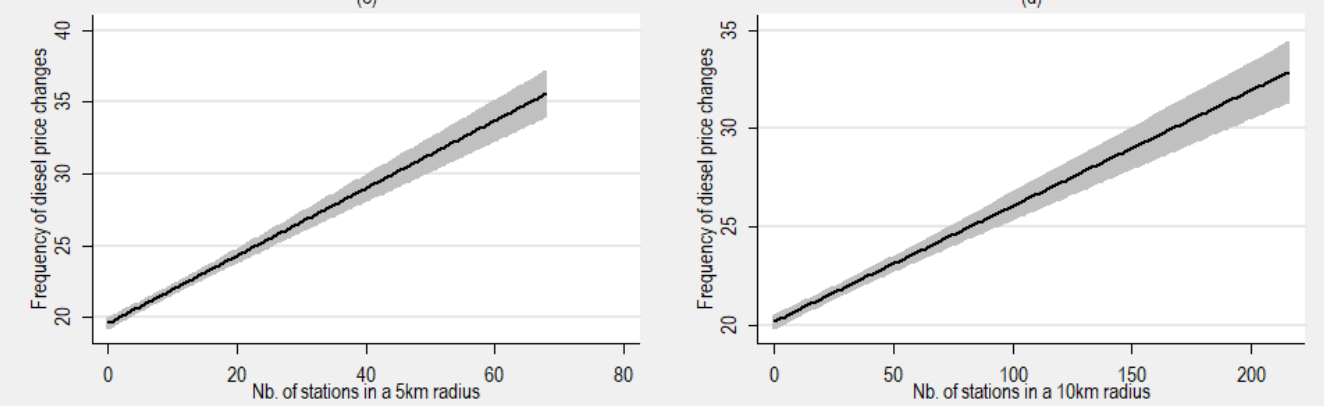

Note: Fitted regression lines obtained on the total sample of gas stations ( 8,064 observations) by regressing the frequency of price changes on the four proxies for local competition. A $95 \%$ confidence interval is considered. 
ing our measure of price stickiness, i.e. the frequency of price changes, Comp is a $n \times 1$ vector of observations on one of our four proxies for local competition (COMP1, COMP2, COMP3, COMP4), and $X \equiv\{$ supermarket, independent retailer, number of services, price level, rural area, medium urban area, big urban area, Paris area, median household income, unemployment rate, number of campings, share of households owning one car, constant $\}$ is a $n \times k+1$ matrix of observations of on a set of $k+1$ explanatory variables $6, \varepsilon_{i}$ is the random error term, a $n \times 1$ vector. We also include dummy variables for departments to capture potential unobserved heterogeneity between departments. Throughout the study, we will be primarily interested in the sign and significance of the estimated coefficient $\hat{\gamma}$. Equation (1) is estimated using the Ordinary Least Squares (OLS) estimator.

Table 3 reports the results obtained by the estimation of equation (1). Specification [1] presents the coefficient estimates with the distance in $\mathrm{km}$ to the nearest station as proxy for local competition (COMP1), while specifications [2], [3] and [4] present the coefficient estimates when we consider the number of gas stations within a $3 \mathrm{~km}$ (COMP2), 5km (COMP3) and $10 \mathrm{~km}$ (COMP4) radius as proxies for competition. Consistent with the preliminary descriptive statistics, we can observe a negative and significant relationship between the distance to the nearest gas station and the frequency of price changes. Conversely, this relationship appears positive and significant when we consider the number of stations within a given radius as proxy for local competition. This confirms the fact that gas stations are more likely to change their prices more frequently if they face a high competitive pressure.

Concerning control variables, results are overall those expected. Then, for all specifications, we find that supermarket chains and independent retailers are characterized by a lower price flexibility than other gas stations, i.e. stations belonging to major oil companies. The coefficient associated with these two dummy variables are negative and statistically significant at the $1 \%$ level. An opposite sign is obtained concerning the number of services offered in gas stations. Indeed, for specifications [1] to [4], our results indicate that the number of services has a positive significant effect on the frequency of price changes. Furthermore, as expected, we find a negative and significant relationship between the price level and the frequency of price changes.

The city size seems also to explain the degree of price rigidity. Indeed, for all specifications, results show a positive and significant relationship between the urban area dummies and the frequency of price changes. Conversely, we can observe a negative and significant relationship between the rural area dummy and the frequency of price changes. Such results suggest therefore that the intensity of the demand addressed to gas stations, and then their volume of sales, is an important driver of the price-setting behavior of fuel retailers. As Gautier and Le Saout (2015, 2017), results concerning the

\footnotetext{
${ }^{6}$ see Table A2 in Appendix for a detailed description of these variables.
} 
binary variable capturing the fact that a gas station is located in Paris and its region are more mixed. Only specification [1] shows a positive and significant relationship between this dummy variable and the frequency of diesel price changes.

Concerning the control variables proxying the local population characteristics and the demand profile, we find more stable results. Thus, for all specifications, we find that the frequency of price changes is positively and significantly related to the median household income, the unemployment rate and the share of households owning a car. Nonetheless, in line with Pennerstorfer and Weiss (2013), who argue that a large number of tourists could indicate a larger share of uninformed consumers, we do not find that the importance of tourism in a municipality, proxied in our case by the number of campings, significantly impact the pricing policy of gas stations and their degree of price flexibility.

We check the robustness of our empirical findings by considering alternative sets of control variables. First, following Chouinard and Perloff (2007) and Pennerstorfer and Weiss (2013), we replace dummies capturing the city size and the fact that a gas station is located in Paris and its region by the logarithm of the population density. Second, we replace the annual median household income by the average net hourly wage of the municipality where each gas station is located. Finally, we replace the number of campings in each municipality by the number of holiday villages as a proxy for tourism intensity.

Results that we obtain are very similar to those reported in Table 3 . Thus, they confirm the fact the city size is an important determinant of the degree price stickiness on the fuel retail market. Consistent with our previous findings, we find a positive and significant relationship between the population density and the frequency of price changes. Concerning the average net hourly wage, coefficient estimates exhibit the same sign and level of significance than for the annual median household income. Similarly to results reported above, we do not find a significant relationship between the tourism intensity and our measure of price stickiness. More importantly, coefficients estimates associated with our proxies for local competition remain statistically significant and with the expected sign. This confirms therefore that gas stations facing a high competitive pressure are more likely to adjust their prices more quickly and more frequently in response to crude oil price decreases than stations enjoying market power.

\footnotetext{
${ }^{7}$ Results of robustness checks are available upon request.
} 
Table 3: Local competition and the frequency of price changes: OLS estimates

\begin{tabular}{|c|c|c|c|c|}
\hline & {$[1]$} & {$[2]$} & {$[3]$} & {$[4]$} \\
\hline & STICKY & STICKY & STICKY & STICKY \\
\hline COMP1 & $\begin{array}{c}-0.192^{* * *} \\
(0.048)\end{array}$ & & & \\
\hline COMP2 & & $\begin{array}{c}0.306^{* * *} \\
(0.053)\end{array}$ & & \\
\hline COMP3 & & & $\begin{array}{c}0.182^{* * *} \\
(0.026)\end{array}$ & \\
\hline COMP4 & & & & $\begin{array}{c}0.061^{* * *} \\
(0.010)\end{array}$ \\
\hline Supermarket & $\begin{array}{c}-4.404^{* * *} \\
(0.455)\end{array}$ & $\begin{array}{c}-4.244^{* * *} \\
(0.452)\end{array}$ & $\begin{array}{c}-4.255^{* * *} \\
(0.457)\end{array}$ & $\begin{array}{c}-4.387^{* * *} \\
(0.457)\end{array}$ \\
\hline Independent retailer & $\begin{array}{c}-6.344^{* * *} \\
(0.532)\end{array}$ & $\begin{array}{c}-6.308^{* * *} \\
(0.534)\end{array}$ & $\begin{array}{c}-6.276^{* * *} \\
(0.532)\end{array}$ & $\begin{array}{c}-6.297^{* * *} \\
(0.532)\end{array}$ \\
\hline Number of services & $\begin{array}{c}0.531^{* * *} \\
(0.035)\end{array}$ & $\begin{array}{c}0.534^{* * *} \\
(0.035)\end{array}$ & $\begin{array}{c}0.533^{* * *} \\
(0.035)\end{array}$ & $\begin{array}{c}0.534^{* * *} \\
(0.035)\end{array}$ \\
\hline Price level & $\begin{array}{c}-163.250^{* * *} \\
(5.195)\end{array}$ & $\begin{array}{c}-162.985^{* * *} \\
(5.164)\end{array}$ & $\begin{array}{c}-163.113^{* * *} \\
(5.151)\end{array}$ & $\begin{array}{c}-163.636^{* * *} \\
(5.168)\end{array}$ \\
\hline Rural area & $\begin{array}{c}-1.725^{* * *} \\
(0.381)\end{array}$ & $\begin{array}{c}-2.073^{* * *} \\
(0.334)\end{array}$ & $\begin{array}{c}-2.191^{* * *} \\
(0.331)\end{array}$ & $\begin{array}{c}-2.280^{* * *} \\
(0.332)\end{array}$ \\
\hline Medium urban area & $\begin{array}{c}2.727^{* * *} \\
(0.317)\end{array}$ & $\begin{array}{c}2.137^{* * *} \\
(0.345)\end{array}$ & $\begin{array}{c}2.080^{* * *} \\
(0.338)\end{array}$ & $\begin{array}{c}2.534^{* * *} \\
(0.321)\end{array}$ \\
\hline Major urban area & $\begin{array}{c}3.406^{* * *} \\
(0.363)\end{array}$ & $\begin{array}{c}2.420^{* * *} \\
(0.404)\end{array}$ & $\begin{array}{c}1.767^{* * *} \\
(0.433)\end{array}$ & $\begin{array}{c}2.148^{* * * *} \\
(0.418)\end{array}$ \\
\hline Paris and its region & $\begin{array}{c}2.189^{* *} \\
(0.997)\end{array}$ & $\begin{array}{c}0.859 \\
(1.032)\end{array}$ & $\begin{array}{c}-0.129 \\
(1.085)\end{array}$ & $\begin{array}{c}-0.746 \\
(1.153)\end{array}$ \\
\hline Median household income (log) & $\begin{array}{c}3.681^{* * *} \\
(1.382)\end{array}$ & $\begin{array}{c}3.876^{* * *} \\
(1.371)\end{array}$ & $\begin{array}{c}3.376^{* *} \\
(1.369)\end{array}$ & $\begin{array}{c}3.080^{* *} \\
(1.371)\end{array}$ \\
\hline Unemployment rate $(\%)$ & $\begin{array}{c}0.154^{* * *} \\
(0.040)\end{array}$ & $\begin{array}{c}0.113^{* * *} \\
(0.041)\end{array}$ & $\begin{array}{c}0.117^{* * *} \\
(0.040)\end{array}$ & $\begin{array}{c}0.151^{* * * *} \\
(0.040)\end{array}$ \\
\hline Number of campings & $\begin{array}{l}-0.036 \\
(0.043)\end{array}$ & $\begin{array}{l}-0.030 \\
(0.042)\end{array}$ & $\begin{array}{l}-0.017 \\
(0.042)\end{array}$ & $\begin{array}{l}-0.017 \\
(0.042)\end{array}$ \\
\hline Households owning a car (\%) & $\begin{array}{c}1.699^{* * *} \\
(0.246)\end{array}$ & $\begin{array}{c}1.661^{* * *} \\
(0.246)\end{array}$ & $\begin{array}{c}1.563^{* * *} \\
(0.249)\end{array}$ & $\begin{array}{c}1.480^{* * *} \\
(0.251)\end{array}$ \\
\hline Number of observations & 8.064 & 8.064 & 8.064 & 8.064 \\
\hline R-squared & 0.414 & 0.417 & 0.419 & 0.416 \\
\hline
\end{tabular}

Note: This table shows the regression results with the frequency of price changes as dependent variable. COMP1 refers the distance in $\mathrm{km}$ to the nearest gas station, COMP2, COMP3 and COMP4 refer to the number of stations within a $2 \mathrm{~km}$, a $5 \mathrm{~km}$, and a $10 \mathrm{~km}$ radius, respectively. Robust standard errors are reported below their coefficient estimates. Constant and dummy variables for departments are included but are not reported.

$*, * *$ and $* * *$ indicate statistical significance at the $10 \%, 5 \%$ and $1 \%$ level, respectively. 


\subsection{Spatial estimates}

The main feature of geographical data is that they could exhibit spatial autocorrelation (LeSage and Pace, 2009). In other words, beyond the geographical proximity of gas stations, we can imagine that the pricing policy of stations, and then their degree of price stickiness, strongly depends on the price-setting behavior of their local competitors (see, e.g., Atkinson et al., 2009). In particular, one can expect a higher price flexibility for a gas station whose nearby competitors change their prices more frequently than for a gas station whose nearby competitors are characterized by a higher degree of price stickiness.

To deal with such a spatial autocorrelation that accommodates forms of crossretailer interactions, we estimate a spatial-autoregressive (SAR) model where an additional independent variable ( $W^{*}$ Sticky) known as a spatial lag is included. This new variable models contemporaneous interactions between game stations. Each observation of this spatial-lag variable is a weighted average of the values of the dependent variable (Sticky) observed for the other cross-sectional gasoline retailers.

The SAR model is defined as follows:

$$
\text { Sticky }=\rho W^{*} \text { Sticky }+\gamma \operatorname{Comp}+\beta X+\varepsilon
$$

where

$$
\begin{aligned}
& \text { Sticky }=\left[\begin{array}{c}
\text { Sticky } \\
\vdots \\
\text { Stick } y_{n}
\end{array}\right], W=\left[\begin{array}{ccccc}
0 & w_{1,2} & \ldots & w_{1, n-1} & w_{1, n} \\
w_{2,1} & 0 & \ldots & w_{2, n-1} & w_{2, n} \\
\vdots & \vdots & \ddots & \vdots & \vdots \\
w_{n-1,1} & w_{n-1,2} & \ldots & 0 & w_{n, n-1} \\
w_{n, 1} & w_{0,2} & \ldots & w_{0, n-1} & 0
\end{array}\right], \text { Comp }=\left[\begin{array}{c}
\text { Comp } \\
1 \\
\vdots \\
\text { Comp }_{n}
\end{array}\right], \\
& X=\left[\begin{array}{ccc}
X_{1,1} & \ldots & X_{1, k} \\
\vdots & \ddots & \vdots \\
X_{n, 1} & \ldots & X_{n, k}
\end{array}\right] \text {, and } \varepsilon=\left[\begin{array}{c}
\varepsilon_{1} \\
\vdots \\
\varepsilon_{n}
\end{array}\right] \text { the innovation vector. }
\end{aligned}
$$

$W$ is known as the interaction matrix or contiguity matrix and $\rho$ is the SAR parameter. The spatial autoregressive parameter measures the intensity of the contemporaneous interactions in the neighborhood of a gas station. If the $\rho$ coefficient is statistically different from zero, we face evidence of transmission of price stickiness across gas stations. The distance, expressed in kilometers, between gas stations $i$ and $j\left(w_{i, j}\right)$ corresponds to the Euclidean distance. Equation (2) is estimated using the Maximum Likelihood (ML) estimator and the min-max method is used to normalise the interaction matrix. It means that each element $w_{i, j}$ is divided by the minimum of the largest row sum and column sum of the $W$ matrix 8 . As previously, we include dummy variables for

\footnotetext{
${ }^{8}$ Given the normalization of the spatial-weighting matrix, the parameter space for $\rho$ is the interval
} 
departments to capture potential unobserved heterogeneity between departments.

Results that we obtain are reported in Table 4. Similarly to Table 3 , specification [1] presents the coefficient estimates with the distance in $\mathrm{km}$ to the nearest station as proxy for local competition (COMP1), while specifications [2], [3] and [4] present the coefficient estimates when we consider the number of gas stations within a $3 \mathrm{~km}$ (COMP2), 5km (COMP3) and $10 \mathrm{~km}$ (COMP4) radius as proxies for competition. We can observe in specifications [1] to [4] that the coefficient of the spatial lag $(\rho)$ is positive and statistically significant at the conventional levels. This confirms that the price-setting behavior of gas stations is also driven by the pricing policy of their local competitors, and then justifies our choice of considering a spatial specification.

More importantly, results of the SAR model confirm those obtained with the OLS estimator. Indeed, we still find that the estimated coefficient associated with COMP1 is negative and statistically significant at the $1 \%$ level, while we find the opposite sign for COMP2, COMP3 and COMP4.

$[-1,1]$. 
Table 4: Local competition and the frequency of price changes: Spatial estimates

\begin{tabular}{|c|c|c|c|c|}
\hline & [1] & {$[2]$} & {$[3]$} & {$[4]$} \\
\hline & STICKY & STICKY & STICKY & STICKY \\
\hline SAR parameter $(\rho)$ & $\begin{array}{c}0.163^{* *} \\
(0.066)\end{array}$ & $\begin{array}{c}0.212^{* *} \\
(0.095)\end{array}$ & $\begin{array}{c}0.185^{*} \\
(0.095)\end{array}$ & $\begin{array}{l}0.176^{*} \\
(0.095)\end{array}$ \\
\hline COMP1 & $\begin{array}{c}-0.190^{* * *} \\
(0.047)\end{array}$ & & & \\
\hline COMP2 & & $\begin{array}{c}0.304^{* * *} \\
(0.039)\end{array}$ & & \\
\hline COMP3 & & & $\begin{array}{c}0.180^{* * *} \\
(0.021)\end{array}$ & \\
\hline COMP4 & & & & $\begin{array}{c}0.060^{* * *} \\
(0.009)\end{array}$ \\
\hline Supermarket & $\begin{array}{c}-4.376^{* * *} \\
(0.331)\end{array}$ & $\begin{array}{c}-4.215^{* * *} \\
(0.330)\end{array}$ & $\begin{array}{c}-4.232^{* * *} \\
(0.329)\end{array}$ & $\begin{array}{c}-4.365^{* * *} \\
(0.329)\end{array}$ \\
\hline Independent retailer & $\begin{array}{c}-6.327^{* * * *} \\
(0.663)\end{array}$ & $\begin{array}{c}-6.293^{* * *} \\
(0.661)\end{array}$ & $\begin{array}{c}-6.264^{* * *} \\
(0.661)\end{array}$ & $\begin{array}{c}-6.286^{* * *} \\
(0.662)\end{array}$ \\
\hline Number of services & $\begin{array}{c}0.532^{* * *} \\
(0.032)\end{array}$ & $\begin{array}{c}0.535^{* * *} \\
(0.032)\end{array}$ & $\begin{array}{c}0.534^{* * *} \\
(0.032)\end{array}$ & $\begin{array}{c}0.535^{* * *} \\
(0.032)\end{array}$ \\
\hline Price level & $\begin{array}{c}-163.139^{* * *} \\
(3.189)\end{array}$ & $\begin{array}{c}-162.840^{* * *} \\
(3.179)\end{array}$ & $\begin{array}{c}-162.990^{* * *} \\
(3.175)\end{array}$ & $\begin{array}{c}-163.517^{* * *} \\
(3.180)\end{array}$ \\
\hline Rural area & $\begin{array}{c}-1.731^{* * *} \\
(0.382)\end{array}$ & $\begin{array}{c}-2.073^{* * *} \\
(0.351)\end{array}$ & $\begin{array}{c}-2.191^{* * *} \\
(0.349)\end{array}$ & $\begin{array}{c}-2.280^{* * *} \\
(0.350)\end{array}$ \\
\hline Medium urban area & $\begin{array}{c}2.740^{* * * *} \\
(0.329)\end{array}$ & $\begin{array}{c}2.155^{* * *} \\
(0.339)\end{array}$ & $\begin{array}{c}2.101^{* * *} \\
(0.338)\end{array}$ & $\begin{array}{c}2.553^{* * * *} \\
(0.330)\end{array}$ \\
\hline Major urban area & $\begin{array}{c}3.404^{* * *} \\
(0.352)\end{array}$ & $\begin{array}{c}2.433^{* * *} \\
(0.377)\end{array}$ & $\begin{array}{c}1.792^{* * *} \\
(0.402)\end{array}$ & $\begin{array}{c}2.183^{* * *} \\
(0.403)\end{array}$ \\
\hline Paris and its region & $\begin{array}{c}2.092^{* *} \\
(0.989)\end{array}$ & $\begin{array}{c}0.787 \\
(1.002)\end{array}$ & $\begin{array}{c}-0.172 \\
(1.021)\end{array}$ & $\begin{array}{c}-0.746 \\
(1.078)\end{array}$ \\
\hline Median household income (log) & $\begin{array}{c}3.742^{* * *} \\
(1.375)\end{array}$ & $\begin{array}{c}3.909^{* * *} \\
(1.369)\end{array}$ & $\begin{array}{c}3.411^{* *} \\
(1.369)\end{array}$ & $\begin{array}{c}3.127^{* *} \\
(1.377)\end{array}$ \\
\hline Unemployment rate (\%) & $\begin{array}{c}0.151^{* * *} \\
(0.042)\end{array}$ & $\begin{array}{c}0.110^{* * *} \\
(0.042)\end{array}$ & $\begin{array}{c}0.115^{* * *} \\
(0.042)\end{array}$ & $\begin{array}{c}0.149^{* * *} \\
(0.041)\end{array}$ \\
\hline Number of campings & $\begin{array}{c}-0.036 \\
(0.047)\end{array}$ & $\begin{array}{c}-0.030 \\
(0.047)\end{array}$ & $\begin{array}{c}-0.017 \\
(0.047)\end{array}$ & $\begin{array}{c}-0.018 \\
(0.047)\end{array}$ \\
\hline Households owning a car (\%) & $\begin{array}{l}-0.707 \\
(0.890)\end{array}$ & $\begin{array}{c}-1.844^{* *} \\
(0.899)\end{array}$ & $\begin{array}{c}-2.512^{* * * *} \\
(0.910)\end{array}$ & $\begin{array}{c}-3.198^{* * *} \\
(0.962)\end{array}$ \\
\hline Number of observations & 8.064 & 8.064 & 8.064 & 8.064 \\
\hline
\end{tabular}

Note: This table shows the regression results with the frequency of price changes as dependent variable. COMP1 refers the distance in $\mathrm{km}$ to the nearest gas station, COMP2, COMP3 and COMP4 refer to the number of stations within a $2 \mathrm{~km}$, a $5 \mathrm{~km}$, and a $10 \mathrm{~km}$ radius, respectively. The interaction matrix is different in each specification since the neighborhood of a gas station varies according to the definition of the local competition. Standard errors are reported below their coefficient estimates. Constant and dummy variables for departments are included but are not reported.

$*,{ }^{*}$ and ${ }^{* * *}$ indicate statistical significance at the $10 \%, 5 \%$ and $1 \%$ level, respectively. 


\section{Conclusion}

The academic literature provides manifold explanations for sticky prices? Among them, we find for instance the cost-based pricing, the contractual arrangements between the firms and their customers, the menu and informational costs, the attractive pricing strategies, the buyers' habit of judging quality by price, and the lack of competition. Indeed, it is often argued that pricing policies of firms facing less competition are more rigid than firms operating in competitive markets. This paper uses the French retail gasoline market as a study framework to explore this issue.

Using individual gasoline prices collected at a daily frequency for more than 8,000 French gas stations from May 2nd, 2012 to April 30th, 2013, we empirically analyse whether the degree of local competition impacts the price-setting behavior of gas stations, and is negatively linked to the degree of price stickiness. In other words, whether a greater competition between gas stations induces a higher flexibility of fuel retail prices. To this end, we consider the frequency of price changes as an inverse measure of price stickiness. The degree of local competition is measured using the geocoordinates of each station and consists of the distance in $\mathrm{km}$ to the nearest station, and of the number of gas stations within a $3 \mathrm{~km}, 5 \mathrm{~km}$ and $10 \mathrm{~km}$ radius.

Results that we obtain show that the frequency of price changes is positively and significantly related to the degree of local competition. Our findings confirm therefore that the intensity of competition on the retail gasoline market is an important driver of the price-setting behavior of firms, who can make the choice to more or less respond to wholesale price changes according to the degree of local competition they face and the characteristics of the local market. Moreover, we show that the relationship between competition and the rigidity of gasoline pump prices also plays through the pricing policy of local competitors. Indeed, our spatial estimates indicate that the degree of price stickiness of neighboring service stations significantly impacts the pricing policy of gas stations and plays a key role in price rigidity patterns.

Our findings have important implications in terms of competition policy. As for many other markets, they suggest that enhancing competition between firms is an effective way for improving consumer welfare. Over the last decade, in a number of industrialized countries, several measures have been taken by competition agencies for promoting more competition on road fuel markets and avoiding tacit collusion between gasoline retailers. However, as recognised by the OECD (2013), identifying price-fixing arrangements and proving the existence of unlawful anti-competitive behavior is not always easy for competition authorities. Indeed, the fact that gas stations operating in a same geographical area adopt a similar price-setting behavior can be simply the result of a rational and spontaneous independent response of each firm to the expected pricing

\footnotetext{
${ }^{9}$ See Fabiani et al. (2005) for a review of theories devoted to the question of price stickiness.
} 
policy of its competitors (see, e.g., Bishop and Walker, 2002). In response to these difficulties, some competition agencies have recently made the choice to increase price transparency on the fuel retail market by providing for instance price sharing services to motorists. The objective is to reduce consumer search costs when comparing prices between different gas stations, and then increase competition between fuel retailers. 


\section{References}

Alvarez, L.J. and Hernando, I. (2006). Competition and price adjustment in the Euro area. Fabiani, S., Loupias, C., Martins, F. and Sabbatini, R. (Eds.), Pricing Decisions in the Euro Area: How Firms Set Prices and Why, Oxford University Press.

Angelopoulou, E. and Gibson, H.D. (2010). The determinants of retail petrol prices in Greece. Economic Modelling 27(6), 1637-1542.

Atkinson, B., Eckert, A. and West, D.S. (2009). Price matching and the domino effect in a retail gasoline market. Economic Inquiry 47(3), 568-588.

Bachmeier, L.J. and Griffin, J.M. (2003). New evidence on asymmetric gasoline price responses. Review of Economics and Statistics 85(3), 772-776.

Bacon, R.W. (1991). Rockets and feathers: The asymmetric speed of adjustment of UK retail gasoline prices to cost changes. Energy Economics 13(3), 211-218.

Balmaceda, F. and Soruco, P. (2008). Asymmetric dynamic pricing in a local gasoline retail market. Journal of Industrial Economics 56(3), 629-653.

Barron, J.M., Taylor, B.A. and Umbeck, J.R. (2004). Number of sellers, average prices, and price dispersion. International Journal of Industrial Organization 22(8-9), 1041-1066.

Baudry, L., Le Bihan, H., Sevestre, P. and Tarrieu, S. (2007). What do thirteen million price records have to say about consumer price rigidity? Oxford Bulletin of Economics and Statistics 69(2), 139-183.

Bedrossian, A. and Moschos, D. (1988). Industrial structure, concentration and the speed of price adjustment. Journal of Industrial Economics 36(4), 459-475.

Bils, M. and Klenow, P.J. (2004). Some evidence on the importance of sticky prices. Journal of Political Economy 112(5), 947-985.

Bishop, S. and Walker, M. (2002). The Economics of EC competition Law: Concepts, Application and Measurement. Sweet \& Maxwell, London.

Borenstein, S., Cameron, A.C. and Gilbert, R. (1997). Do gasoline prices respond asymmetrically to crude oil price changes? Quarterly Journal of Economics 112(1), 
305-339.

Cabral, L. and Fishman, A. (2012). Business as usual: A consumer search theory of sticky prices and asymmetric price adjustment. International Journal of Industrial Organization 30(4), 371-376.

Carlton, D.W. (1986). The rigidity of prices. American Economic Review 76(4), $637-658$

Chouinard, H.H. and Perloff, J.M. (2007). Gasoline price differences: Taxes, pollution regulations, mergers, market power, and market conditions. The B.E. Journal of Economic Analysis \& Policy 7(1), Article 8.

Clemenz, G. and Gugler, K. (2006). Locational choice and price competition: Some empirical results for the Austrian retail gasoline market. Empirical Economics 31(2), 291-312.

Cornille, D. and Dossche, M. (2006). The patterns and determinants of price setting in the Belgian industry. ECB Working Paper No. 618, European Central Bank.

Deltas, G. (2008). Retail gasoline price dynamics and local market power. Journal of Industrial Economics 56(3), 613-628.

Dixon, R. (1983). Industry structure and the speed of price adjustment. Journal of Industrial Economics 32(1), 25-37.

Douglas, C. (2010). Do gasoline prices exhibit asymmetry? Not usually! Energy Economics 32(4), 918-925.

Eckert, A. (2003). Retail price cycles and the presence of small firms. International Journal of Industrial Organization 21(2), 151-170.

Eckert, A. (2013). Empirical studies of gasoline retailing: A guide to the literature. Journal of Economic Surveys 27(1), 140-166.

Eckert, A. and West, D.S. (2005). Price uniformity and competition in a retail gasoline market. Journal of Economic Behavior and Organization 56(2), 219-237.

Edgeworth, F.Y. (1925). The pure theory of monopoly. Papers Relating to Political Economy, vol. 1, 111-142. London: McMillan. 
Encaoua, D. and Geroski, P.A. (1986). Price dynamics and competition in five OECD countries. OECD Economic Studies 6, 47-74.

Fabiani, S., Druant, M., Hernando, I., Kwapil, C., Landau, B., Loupias, C., Martins, F., Mathä, T., Sabbatini, R., Stahl, H. and Stokman, A. (2005). The pricing behaviour of firms in the Euro area - New survey evidence. ECB Working Paper No. 535, European Central Bank.

Fabiani, S., Druant, M., Hernando, I., Kwapil, C., Landau, B., Loupias, C., Martins, F., Mathä, T., Sabbatini, R., Stahl, H. and Stokman, A. (2006). What firms' surveys tell us about price-setting behavior in the Euro area. International Journal of Central Banking 2(3), 3-47.

Gautier, E. and Le Saout, R. (2015). The dynamics of gasoline prices: Evidence from daily French micro data. Journal of Money, Credit and Banking 47(6), 10631089 .

Gautier, E. and Le Saout, R. (2017). L'ajustement microéconomique des prix des carburants en France. Economie et Prévisions 210, 1-24.

Geweke, J. (2004). Issues in the "rockets and feathers" gasoline price literature. Report to the Federal Trade Commission, University of Iowa.

Ginsburgh, V. and Michel, P. (1988). Adjustment costs, concentration and price behaviour. Journal of Industrial Economics 36(4), 477-481.

Green, E.J. and Porter, R.H. (1984). Noncooperative collusion under imperfect price information. Econometrica 52(1), 87-100.

Hannan, Y. and Berger, A.N. (1991). The rigidity of prices: Evidence from the banking industry. American Economic Review 81(4), 938-945.

Harding, M. (2014). The diesel differential: Differences in the tax treatment of gasoline and diesel for road use. OECD Taxation Working Papers No.21, OECD Publishing.

Hastings, J.S. (2004). Vertical relationships and competition in retail gasoline markets: Empirical evidence from contract changes in Southern California. American Economic Review 94(1), 317-328. 
Hastings, J.S. and Shapiro, J.M. (2013). Fungibility and consumer choice: Evidence from commodity price shocks. The Quarterly Journal of Economics 128(4), 1449-1498.

Haucap, J., Heimeshoff, U. and Siekmann, M. (2017). Fuel prices and station heterogeneity on retail gasoline markets. The Energy Journal 38(6), 81-103.

Hosken, D.S., McMillan, R.S. and Taylor, C.T. (2008). Retail gasoline pricing: What do we know? International Journal of Industrial Organization 26(6), 1425-1436.

Houde, J-F. (2012). Spatial differentiation and vertical mergers in retail markets for gasoline. American Economic Review 102(5), 2147-2182.

Kihm, A., Ritter, N. and Vance, C. (2014). Is the German retail gas market competitive? A spatial-temporal analysis using quantile regression. RUHR Economic Papers 522, Ruhr-Universität Bochum, Germany.

LeSage, J. and Pace, R. K. (2009). Introduction to Spatial Econometrics, CRC Press, Taylor and Francis Group, New York.

Lewis, M.S. (2011). Asymmetric price adjustment and consumer search: An examination of the retail gasoline market. Journal of Economics and Management Strategy 20(2), 409-449.

Lewis, M.S. (2015). Odd prices at retail gasoline stations: Focal point pricing and tacit collusion. Journal of Economics and Management Strategy 24(3), 664-685.

Martin, C. (1993). Price adjustment and market structure. Economics Letters 41(2), 139-143.

Marvel, H.P. (1976). The economics of information and retail gasoline price behavior: An empirical analysis. Journal of Political Economy 84(5), 1033-1060.

Maskin, E. and Tirole, J. (1988). A theory of dynamic oligopoly, II: Price competition, kinked demand curves, and Edgeworth cycles. Econometrica 56(3), 571-599.

Noel, M.D. (2007a). Edgeworth price cycles, cost-based pricing, and sticky pricing in retail gasoline markets. Review of Economics and Statistics 89(2), 324-334.

Noel, M.D. (2007b). Edgeworth price cycles: Evidence from the Toronto retail gasoline market. Journal of Industrial Economics 55(1), 69-92. 
OECD. (2013). Competition in road fuel - Policy roundtables. Organisation for Economic Co-operation and Development, June 2013.

Peltzman, S. (2000). Prices rise faster than they fall. Journal of Political Economy 108(3), 466-502.

Pennerstorfer, D. and Weiss, C. (2013). Spatial clustering and market power: Evidence from the retail gasoline market. Regional Science and Urban Economics 43(4), 661-675.

Pennerstorfer, D., Schmidt-Dengler, P., Schutz, N., Weiss, C. and Yontcheva, B. (2014). Information and price dispersion: Evidence from retail gasoline. Mimeo.

Perdiguero-Garcia, J. (2013). Symmetric or asymmetric oil prices? A meta-analysis approach. Energy Policy 57, 389-397.

Remer, M. (2015). An empirical investigation of the determinants of asymmetric pricing. International Journal of Industrial Organization 42, 46-56.

Salop, S.C. (1979). Monopolistic competition with outside goods. Bell Journal of Economics 10(1), 141-156.

Sen, A. (2003). Higher prices at Canadian gas pumps: International crude oil prices or local market concentration? An empirical investigation. Energy Economics 25(3), 269-288.

Sen, A. (2005). Does increasing the market share of smaller firms result in lower prices? Empirical evidence from the Canadian gasoline industry. Review of Industrial Organization 26(4), 371-389.

Stahl, D.O. (1989). Oligopolistic pricing with sequential consumer search. American Economic Review 79(4), 700-712.

Stiglitz, J.E. (1984). Price rigidities and market structure. American Economic Review 74(2), 350-355.

Tappata, M. (2009). Rockets and feathers: Understanding asymmetric pricing. RAND Journal of Economics 40(4), 673-687. 
Van Meerbeeck, W. (2003). Competition and local market conditions on the Belgian retail gasoline market. De Economist 151(4), 369-388.

Varian, H.R. (1980). A model of sales. American Economic Review 70(4), 651-659.

Verlinda, J.A. (2008). Do rockets rise faster and feathers fall slower in an atmosphere of local market power? Evidence from the retail gasoline market. Journal of Industrial Economics 56(3), 583-612.

Weiss, C.R. (1995). Determinants of price flexibility in oligopolistic markets: Evidence from Austrian manufacturing. Journal of Economics and Business 47(5), 423-439.

Yang, H. and Ye, L. (2008). Search with learning: Understanding asymmetric price adjustments. RAND Journal of Economics 39(2), 547-564.

Zimmerman, P.R., Yun, J.M. and Taylor, C.T. (2013). Edgeworth price cycles in gasoline: Evidence from the United States. Review of Industrial Organization 42(3), 297-320. 
Appendix

Table A1: Descriptive statistics

\begin{tabular}{lccccc}
\hline Variable & Nb. obs & Mean & Std. Dev & Min & Max \\
\hline STICKY & 8064 & 21.44 & 12.66 & 0.59 & 100 \\
COMP1 & 8064 & 2.10 & 2.81 & 0 & 24.18 \\
COMP2 & 8064 & 3.69 & 4.58 & 0 & 32 \\
COMP3 & 8064 & 7.67 & 10.74 & 0 & 68 \\
COMP4 & 8064 & 21.59 & 35.98 & 0 & 216 \\
Supermarket & 8064 & 0.48 & 0.49 & 0 & 1 \\
Independent retailer & 8064 & 0.03 & 0.16 & 0 & 1 \\
Number of services & 8064 & 6.27 & 3.78 & 1 & 24 \\
Price level & 8064 & 1.40 & 0.05 & 1.26 & 1.81 \\
Rural area & 8064 & 0.16 & 0.36 & 0 & 1 \\
Medium urban area & 8064 & 0.18 & 0.38 & 0 & 1 \\
Major urban area & 8064 & 0.22 & 0.41 & 0 & 1 \\
Paris and its region & 8064 & 0.08 & 0.27 & 0 & 1 \\
Median household income (log) & 8064 & 9.87 & 0.14 & 9.36 & 10.67 \\
Unemployment rate $(\%)$ & 8064 & 13.31 & 4.79 & 0.69 & 38.27 \\
Number of campings & 8064 & 0.89 & 2.52 & 0 & 53 \\
Households owning a car $(\%)$ & 8064 & 47.14 & 2.02 & 34.1 & 51.4 \\
\hline \hline
\end{tabular}




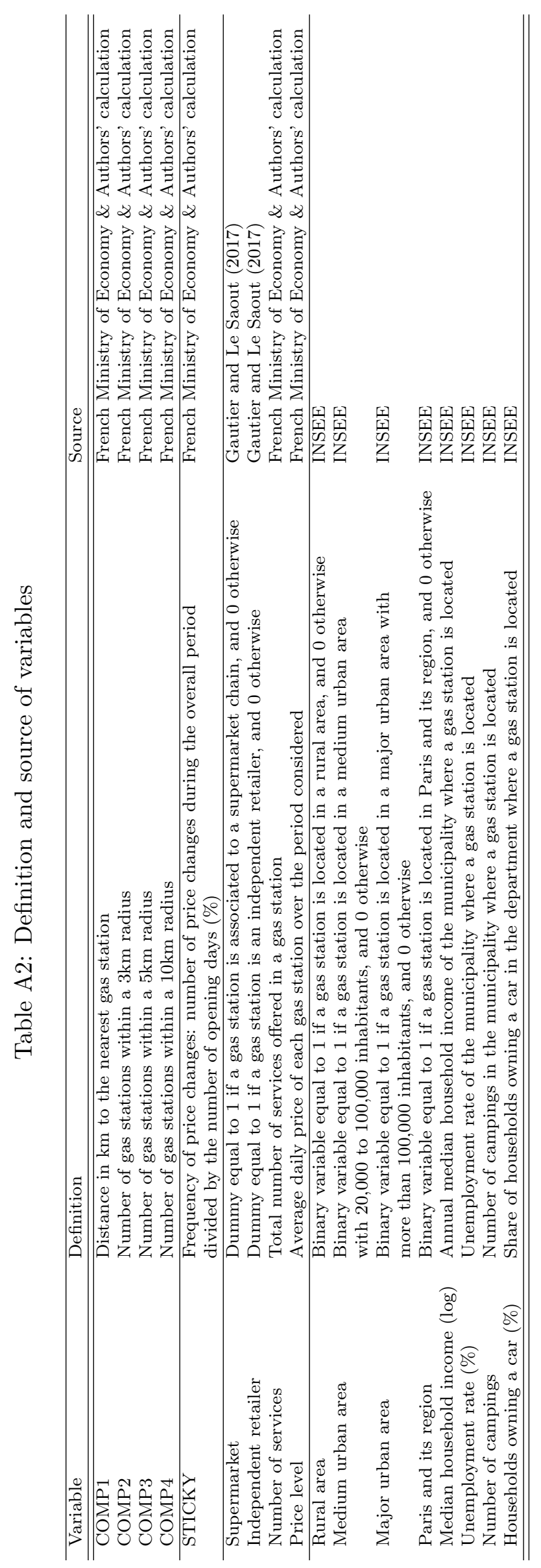

